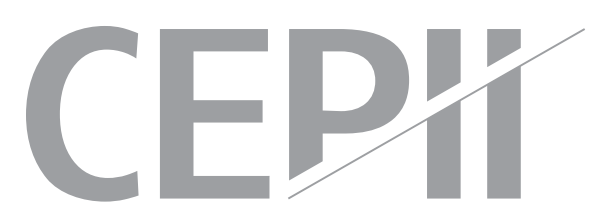

\title{
Impact of European Food Safety Border Inspections on Agri-Food Exports: Evidence from Chinese Firms
}

Matthias Beestermöller, Anne-Célia Disdier \& Lionel Fontagné

\section{Highlights}

- Sanitary regulations introduce an element of uncertainty for exporting firms, in relation to border rejections.

- We examine the impact of restrictive non-tariff measures at firm-level using information on a de facto obstacle: border rejection after inspection.

- After border rejection of a certain product, some Chinese exporters of this product exit the market, there are partially replaced by new entrants, and incumbents increase their market share.

- Border rejection create an informational externality detrimental to small Chiense exporters. 


\section{Abstract}

The cost of complying with a sanitary standard is certain. However, such regulatory measure introduces an element of uncertainty for exporting firms in relation to border rejections. Shipments may fail to pass inspections and may be refused entry into the importing country. This risk is shaped by variance in the quality of the exported product, and the stringency of the border controls. Large developing countries are over-represented in import refusals and may be targeted by inspectors. We examine how the risk of rejection at European borders on safety grounds is affecting Chinese agri-food exporters. We combine information from the European Rapid Alert System for Food and Feed with Chinese firm-level export data by product, destination and year for the period 2000-2011. We show that information externalities and reputation effects are important. Border rejections amplify the turnover among firms at the extensive margin of trade. This risk is curbing small Chinese exporters and resulting in a concentration of Chinese exports from big and more productive exporters.

\section{Keywords}

Food Safety, Border Inspections, Import Refusals, Uncertainty, Firm Heterogeneity.

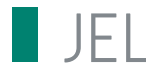

F14, L25, Q17, Q18.

\section{Working Paper}

\section{CEPI}

CEPII (Centre d'Etudes Prospectives et $d^{\prime}$ 'Informations Internationales) is a French institute dedicated to producing independent, policyoriented economic research helpful to understand the international economic environment and challenges in the areas of trade policy, competitiveness, macroeconomics, international finance and growth.
CEPII Working Paper

Contributing to research in international economics

(c) CEPII, PARIS, 2016

All rights reserved. Opinions expressed in this publication are those of the author(s) alone.

$\begin{array}{ll}\text { Editorial Director: } & \text { CEPII } \\ \text { Sébastien Jean } & 113, \text { rue de Grenelle } \\ & 75007 \text { Paris } \\ \text { Production: } & +33153685500 \\ \text { Laure Boivin } & \\ \text { No ISSN: } 1293-2574 & \text { Prw.cepii.fr }\end{array}$




\title{
Impact of European Food Safety Border Inspections on Agri-Food Exports:
} Evidence from Chinese Firms ${ }^{1}$

\author{
Matthias Beestermöller* \\ Anne-Célia Disdier ${ }^{\dagger}$ \\ Lionel Fontagné
}

\section{Introduction}

Trade liberalization drove the average tariff applied to Chinese agri-food exports to the European Union (EU) to a low of $13 \%$ in $2007 .{ }^{2}$ However, access to the European market remains difficult since individual exporters are required to meet regulatory standards, and face procedural obstacles and enforcement. Non-tariff measures (NTMs) act as substantial barriers in the decision to export because they increase the cost of exporting. ${ }^{3}$ This problem is magnified for agri-food products due to stringent sanitary and phytosanitary (SPS) regulations ${ }^{4}$ in most developed markets. Exporters from developing countries - who often hold a comparative advantage in these products - are the most likely to struggle to meet stringent sanitary standards due to inadequate traceability, poor storage, limited access to certification bodies, etc. (Essaji, 2008). While European standards - which often are more restrictive than international ones - are not designed to discriminate against imported goods, exporters in poor countries can be priced out of exporting completely.

NTMs also introduce an element of uncertainty related to possible border rejections if ship-

\footnotetext{
${ }^{1}$ This paper benefited from funding from the European Commission (EC)'s Seventh Framework Programme under Grant Agreement no. 613504 (PRONTO). Views expressed here do not engage the EC. We thank Matthieu Crozet, Carsten Eckel, Peter Egger, Lisandra Flach, Sébastien Jean, Sandra Poncet, Ferdinand Rauch, Georg Schaur, and participants at ETSG 2015, WIIW 2015, the University of Munich seminar, the CEPII seminar, the PSE-Paris 1 Workshop on "Chinese firms in a globalized world", and the CEPR workshop "Quantifying Non-Tariff Barriers to Trade and Investment" for helpful suggestions. Matthias Beestermöller gratefully acknowledges support from the DFG Research Training Group 1928 and Egon-Sohmen-Foundation.

*University of Munich, (matthias.beestermoeller@econ.Imu.de)

${ }^{\dagger}$ corresponding author PSE-INRA, (anne-celia.disdier@ens.fr)

‡PSE-Université Paris 1 \& CEPII, (lionel.fontagne@univ-paris1.fr)

2Source: MAcMap-HS6 database (Guimbard et al., 2012).

${ }^{3} \mathrm{E}$.g., fixed costs such as implementing standards and building up compliance capacities, and recurring costs of documentation for traceability and certification of quality inspections.

${ }^{4}$ Sanitary risk refers to food-borne human illness and animal diseases, and phyto-sanitary risk refers to risks from plant pests and transmission of diseases.
} 
ments do not comply with regulations. The majority of rejections are related to adulteration or misbranding. If exporting firms are unable to meet the required restrictions with a high enough probability, strict regulation and control act as deterrents to trade. Developing country exporters tend to be over-represented in sectors heavily affected by sanitary concerns and import refusals, such as seafood (Baylis et al., 2011). While the cost of matching a standard is certain, being rejected at the importer's border is a risk faced by the exporter. The risk is shaped by the variance in the quality of the exported products (which can be reduced by investment in quality or controls prior to shipment) and the stringency of the controls at the border. This latter is observable by the exporter but likely endogenous to past rejections, signaling a high level of variance in the quality of the exported products. This is where externalities among exporters from the same country and/or region can emerge for a given product category since part of the cost of being rejected is borne by competitors from the same exporting country. A spell of rejections ultimately can lead to an outright ban on a product from a particular origin. ${ }^{5}$ In some very specific cases (e.g. past EU ban on imports of genetically modified organisms), negative externalities induced by rejections may have a product rather than a product-country dimension, i.e. all exporters of the same product - whatever their origin - might be affected by a rejection. However, our data suggest that such cases are rare. Most rejections have a product-country dimension and are due to production methods and/or climatic conditions affecting a given country. Taken together, border rejections provide valuable information on NTMs: while details on the occurrence of regulations give evidence on de jure NTMs, knowledge about rejections sheds light on their de facto trade impact ${ }^{6}$

Somewhat surprisingly, the uncertainty component of NTM-related barriers has been mostly overlooked in the literature on NTMs and border inspections. There are four main papers that provide econometric investigations of the impact of import refusals on agri-food trade but none uses firm-level export data. Three papers deal with inspections conducted by the United States (US), while the fourth examines European refusals. Baylis et al. (2009) investigate whether exporters learn from import refusals and whether these refusals are driven by political economy concerns. The analysis is conducted at the macro-level and studies the number of refusals by country of origin, product, and month over the period 1998-2004. The results show that new exporters are less affected than experienced ones by refusals, suggesting that inspections are not random but are targeted at exporters identified previously as unsafe. Furthermore, refusals are not driven only by safety concerns but also by domestic political concerns (such as decreased employment in some sectors). Jouanjean et al. (2015) focus more on reputation. Their sample includes US refusals aggregated by country of origin, 4-digit sectors, and year for the period 1998-2008. The authors highlight a neighbor and a sector reputation effect. If the same product from a neighboring country was refused in the previous year, then the odds of a country experiencing at least one import refusal increase by over $100 \%$. At the sector level, the odds of a

\footnotetext{
${ }^{5}$ E.g., in April 2014 the EU banned imports of mangoes from India following the discovery of fruit flies in multiple consignments.

${ }^{6}$ For additional evidence on the importance of distinguishing between de jure and de facto institutions see e.g. Acemoglu and Robinson (2006).
} 
refusal increase by $62 \%$ if a related product from the same country was refused in the preceding year. Grundke and Moser (2014) also adopt an exporter perspective and consider to what extent refusals deter entry in the US. Estimating a gravity equation for 93 product-categories imported to the US in the period 2002-2012, they show that the cost of not complying with US standards is borne by developing countries. EU refusals are used as an instrument because they are expected to be exogenous to US demand. The reasoning made by Grundke and Moser (2014) refers to demand for protection in the US and stricter enforcement of NTMs but like the two previous papers, does not explicitly include uncertainty as a trade barrier. Using data on EU refusals, Jaud et al. (2013) adopt an importer perspective and consider aggregate flows at the product level with no firm dimension. Building on evidence of increasing diversification of EU import sources in agri-food products combined with concentration on a small number of exporting countries, they conclude that entrants start small, while incumbent exporters, which have proved safe, grab most of the EU market share. Although Jaud et al. (2013) also do not mention uncertainty in the import market, the mechanism they refer to is clearly linked to this factor (i.e. sanitary risk in the importing country).

In the present paper we adopt a different perspective: we assess the microeconomic impact of the risk of rejection at the European border on export flows to that market. ${ }^{7}$ We explicitly investigate the effects of rejections on the export decisions of firms serving the European market. Food sanitary standards have become an important policy concern in the EU ${ }^{8}$ making this market particularly sensitive to the issue at stake. While access to the European market has become easier following tariff reductions, exporters in fact face restrictive food safety requirements. Enforcing SPS measures is difficult, especially for firms from developing countries. Most foodstuffs imports have passed through multiple middlemen before reaching supermarket shelves which makes it extremely difficult to trace their origins. While regulatory agencies conduct only spot checks, inspections are not random. Certain countries, firms or products may be subject to special focus. Similarly, repeated controls are not random if the custom officer expects large variance in quality from one shipment to the next. Even under the assumption of an equal distribution of quality failures across countries and random inspections, large countries will be targeted more frequently by rejections in the case of controls which disregard the origin of the products. Overall, China - a large and diversified developing economy which has encountered repeated problems in rich import markets for foodstuff exports - is an interesting case study. Chinese exporters face considerable uncertainty concerning the likelihood and costs involved in exporting since they could well be targeted by controls. We have product level information on individual exports from the universe of Chinese firms exporting to the European market. Although we cannot identify individual exporters that have been rejected, we have information on

\footnotetext{
${ }^{7}$ In this paper, we do not investigate the potential effects of European rejections on exports to non-European markets. These trade diversion and deflection effects have been studied for seafood products by Baylis et al. (2011), who highlight some diversion effects, mostly for products facing relatively non threatening sanitary alerts. In that case, export flows are directed mainly to other high-income countries.

${ }^{8}$ E.g., the 2013 meat adulteration scandal, where food advertised as containing beef was found to contain undeclared horse meat, highlighted the importance of regulations to address market failures.
} 
the product concerned, the product origin (China), and the year of rejection. Thus, studying the effect of the standards that Chinese agri-food exporters must satisfy in the European market is an original approach.

From this perspective our contribution is threefold. Firstly, we add to the growing empirical literature examining the impact of restrictive NTMs at the firm-level using information on de facto NTMs (see for example Fontagné et al., 2015, for a combination of these two dimensions). While not all NTMs are barriers, border rejections represent cases where regulations are enforced, presenting an obstacle to trade. Firm level micro-data allow us to study the effect of these rejections on firms' participation in the export market (extensive margin) and adjustments in the exported value (intensive margin). Also, we pay explicit attention to the role of firm heterogeneity. The theory suggests that large and more productive firms are likely to react differently to NTMs than small firms.

Secondly, to the best of our knowledge, this is the first paper to look at the effect of SPS measures on firm-level exports from a large and significant developing economy. Our data cover the universe of Chinese agri-food exports over a period of more than a decade (2000-2011), and include HS6 product and destination information. Since its accession to the WTO in 2001, China's impressive trade growth has accelerated further. Arguably, China is the world's most dynamic and important economy and exporter. At the same time, anecdotal evidence suggests that Chinese agri-food exporters are struggling to meet sanitary standards. ${ }^{9}$

Thirdly, we focus on a specific trade-impeding indicator of SPS regulations using a rarely exploited dataset of rejections at the European border. ${ }^{10}$ Our de facto NTM measure can be considered as a substantial barrier for exporters. The Rapid Alert System for Food and Feed (RASFF) database records all European border rejections ${ }^{11}$ of shipments due to sanitary concerns. Among other information, it includes the origin of the rejected shipment and a verbal product description. We manually matched the verbal product descriptions in RASFF with HS codes at the 4-digit level of disaggregation. We merged Chinese firm-level data with the RASFF data. The resulting dataset permits us to analyze the impact of border rejections on firms' export decisions.

Our results suggest that border rejections increase firm turnover at the extensive margin of trade. Some Chinese exporters stop exporting to the European market while at the same time, new Chinese firms enter this market. Small firms are affected more strongly than big exporters

\footnotetext{
${ }^{9}$ Frequent scandals, press articles, and anecdote have documented the problems among Chinese exporters to meet sanitary standards. E.g., on Oct. 17, 2012, the German newspaper Der Spiegel pointed to recurring health issues: "In recent years, China has become a major food supplier to Europe. But the low-cost goods are grown in an environment rife with pesticides and antibiotics, disproportionately cited for contamination and subject to an inspection regime full of holes."

${ }^{10}$ The exception again is Jaud et al. (2013), although the data are treated in a totally different way.

${ }^{11}$ Throughout this paper we use the terms import refusal and border rejection interchangeably. As described in Section 3 on the data, we focus on the subset of notifications where a product fails to enter the European market.
} 
by this turnover. In addition, we show some concentration of Chinese exports among big and productive exporters at the intensive margin of trade.

The paper is organized as follows. Section 2 reviews the related literature and the motivation for our research question. Data on border rejections and Chinese firms' exports are presented in Section 3. The empirical strategy is described in Section 4. Section 5 reports the estimation results and robustness checks. Section 6 concludes.

\section{Related literature}

\subsection{Frontiers in research on NTMs}

NTMs have attracted a lot of attention in the recent trade literature. The two main issues highlighted are information sources and trade restrictiveness. Most of the research focuses on agri-food products and related SPS measures because such products raise problems of safety and traceability in an international context. Milestones in this literature stream are Kee et al. (2009)'s measure of NTM trade restrictiveness based on computation of tariff equivalents, and the light that Disdier et al. (2008) shed on the magnified impact of NTMs in the context of developing countries. All these studies face a dilemma: either using indirect evidence on border protection within a gravity perspective which risks capturing much more than NTMs, or using direct - de jure - evidence on the presence of NTMs but based on outdated and incomplete data (such as notifications to the WTO). ${ }^{12}$ However, there are two much more important issues. First, not all NTMs are barriers which casts doubt on the validity of systematic assessment of their trade reducing impact; second, not all exporters are affected equally which suggests to study the impact of these measures at the micro level. Hence, the emphasis on the need to rely on individual firm's response to measures identified as obstacles in Fontagné et al. (2015). We adopt the latter approach, combining information on rejections with Chinese firm level export data. This allows us to explore the impact of NTMs on individual exports in terms of the uncertainty introduced.

\subsection{Uncertainty and export flows}

Most of the large (and old) literature addressing the impact of uncertainty on exports is about exchange rate uncertainty (see e.g. Hooper and Kohlhagen, 1978) and initially concluded that this had a limited impact on aggregate trade volumes. For developing countries the conclusion is more nuanced (Caballero and Corbo, 1989; Grobar, 1993) but this broad statement might overlook a heterogeneous impact among firms. An application to China using microeconomic data is Héricourt and Poncet (2015). The negative impact of real exchange rate volatility on firm-level export performance is magnified when exporters are located in provinces with low financial development.

\footnotetext{
${ }^{12}$ See Chen and Novy (2012) on the distinction between direct and indirect approaches.
} 
Uncertainty in relation to trade costs has been addressed from two perspectives. Firstly, from the point of view of the exporting country, deficient infrastructures (Nordås and Piermartini, 2004) or simply red tape can generate uncertainty about delivery dates and the quality of the batch delivered which is an obstacle to trade. Using information on internal transport costs for a sub-sample of 24 Sub-Saharan countries Freund and Rocha (2011) show that uncertainty about inland transit time reduces export values. An extra-day of time uncertainty - defined as the maximum and the average number of days it takes for an exporter to complete the exporting procedures - induces a 13\% reduction in export values. Building on an argument raised by Francois and Martin (2004) about uncertainty related to water in the tariffs and using a heterogeneous firms model, Handley (2014) shows that trade policy uncertainty delays the entry of exporters into new markets. The argument is that in the presence of sunk entry costs in export markets, uncertainty about future tariffs creates a real option value of waiting. Binding tariffs reduce such uncertainty. Considering the export margins of 149 countries, Osnago et al. (2015) illustrate the effect of trade policy uncertainty at the product level. Controlling for the tariff level, a 1\% reduction in the difference between bound and applied tariffs increases exports by $1 \%$. Feng et al. (2014) focus on China and measure the uneven impact of uncertainty on heterogeneous exporters. Using firm-product data and considering the US market in the years surrounding China's WTO accession, they show that a reduction in tariff uncertainty induces a reallocation of exports across Chinese firms. Entries and exits are boosted, to the real benefit of exporters providing higher quality products at lower prices.

Secondly, uncertainty is an impediment to trade on the importing country side of the transaction. The starting point here is the quality (or safety) of the product, which is not observable. For repeated goods, reputation is based on repeated imports of safe goods from a given origin. What is important is whether the consumer/importer can identify precisely the identity of the exporter. The classical case in the Industrial Organization literature is when the consumer knows the identity of the producer (Shapiro, 1983). The case where the exporter's identity is unknown is more challenging, and applies particularly to commercial relationships with developing countries. In such cases, an expectation of the quality of a product sold by a given firm is formed based on the exporting country's total record of quality problems (in our case, border rejections). Then, individual exporters suffer from the problems encountered by other exporters of the same good from the same country. In an international context, these information externalities can be accommodated - or magnified - by minimum quality standards or origin labeling (Falvey, 1989). Since information externalities are not internalized by the individual exporter, the quality provided by a large country with many firms tends to be low, leading to a collective reputation problem. McQuade et al. (2012) propose a theory related to these effects and argue that it fits the Chinese case well.

We apply our data to the issues of reputation and uncertainty raised in the literature. If the importer cannot distinguish between 'safe' and 'unsafe' trading partners, we expect negative spillovers among Chinese exporters of the same good following a spell of border rejections. 


\section{Data and descriptive statistics}

This section first describes our two main data sources and then provides some descriptive statistics.

\subsection{Data}

Although products subject to sanitary requirements experience systematic pre-shipment controls in the exporting country, random controls at the border of the importing country ensure fairness of the process and retain the possibility of recognizing problems related to transportation. If a problem is identified, the shipment is likely to be rejected. We combine information on rejections of agri-food shipments at the European border with Chinese firm level export data. This allows us to measure the impact of uncertainty (from sanitary riskiness) and regulations on firms' export decisions. Although we cannot identify individual exporters that have been rejected, we have annual information on the product concerned and the origin (China) of the flow.

\section{Food alerts and border rejections}

The RASFF, ${ }^{13}$ created in 1979, consists of a cross-border information exchange system on emergency sanitary measures in the European Economic Area (EEA). ${ }^{14}$ RASFF members must notify the European Commission (EC) about any serious health risk deriving from food or feed. Starting from 1979, all notifications are publicly available via the RASFF portal.

To construct our dataset, we record all notifications by RASFF member states over the period 1979-2012, and make several assumptions:

- First, we treat the RASFF border as the relevant location for observing notifications and consider all notifications by RASFF members regarding non-RASFF countries. We ignore notifications concerning products originating from other RASFF countries.

- Over our sample period, two rounds of RASFF membership enlargements occurred, both of which we account for. The list of RASFF members is reported in Table $1 .{ }^{15}$

- Since we are concerned about rejections due to SPS concerns, we restrict our analysis to agri-food products, i.e. products belonging to chapters 01-24 of the HS classification.

- Some shipments may be rejected but after some improvements - e.g. in the product labeling - allowed entry into the RASFF market. However, the majority of inspected shipments declared 'unsafe' are refused entry into RASFF market permanently. Since we are interested in de facto restrictive rejections, we limit our analysis to this second group of shipments.

\footnotetext{
${ }^{13}$ http://ec.europa.eu/food/safety/rasff/index_en.htm

${ }^{14}$ EEA includes the EU27 countries plus Iceland, Liechtenstein, and Norway.

${ }^{15}$ We exclude Switzerland which from 2009 is included in RASFF border controls of products of animal origin but not in other types of controls.
} 
Using information available on the RASFF portal, we can identify whether or not future entry was allowed. We retain only observations related to permanent import refusals. ${ }^{16}$

- If a rejection specifies two origin countries, we split the observation into two: one for each origin.

After these cleaning procedures, we have a total of 14,860 rejections during the period 1979$2011,1,690$ of which are related to Chinese shipments.

The RASFF portal contains information on products only in verbal form. We coded the rejection data at the HS 4-digit level - the most disaggregated level at which we can identify rejections. A detailed description of the applied methodology is provided in Appendix A. Using this approach, we are able to match $89 \%$ of all rejections with an HS4 code $(13,241$ out of 14,860$)$, and $91 \%$ of Chinese rejections $(1,537$ out of 1,690$)$.

Insert Table 1 here

\section{Chinese exports at the firm-level}

Chinese customs data ${ }^{17}$ provide information on exports by firm, product (6-digit of the HS classification), destination and year. Our dataset covers the period 2000-2011. Customs data, which include the universe of Chinese exports, are preferable to surveys often used in the literature since customs data avoid stratification or sampling issues such as selection effects.

In our empirical analysis, we restrict our attention to non-wholesalers. While intermediaries play an important role in trade, we want to focus on the direct decisions of firms. Intermediaries might display different export behavior and might react less strongly to border rejections.

We aggregate all exports by firm-destination-year at the HS4 level (the level at which we code border rejections). It is possible that some firms might export different HS6 products within one HS4 sector. To address this concern, we verify that the large majority of HS4-firm observations also uniquely identify an HS6 shipment (see Table B.2 in Appendix B). Even among multi-HS4 product firms, around $70 \%$ of HS4 sectors include only a single HS6 product. ${ }^{18}$

\footnotetext{
${ }^{16}$ More precisely for the period 2008-2012, we use information on border rejections, which is reported on the RASFF portal and refers to consignments that have failed entry to the RASFF market and which are not allowed to enter through another border post. Before 2008, this precise information on border rejections was not available. We exploit information on notifications and on the action taken by RASFF authorities (e.g. import not authorized; product destruction; product placed under customs seals; destruction or return after official permission; re-export to a third market; containers detained) to identify import refusals.

${ }^{17}$ We thank Sandra Poncet for providing the data.

${ }^{18}$ Table B.2 shows also that the majority of firms are present in only one HS4 sector. Therefore, in our sample spillovers within firms and across HS4 sectors are likely to be small.
} 


\subsection{Descriptive statistics}

Table 2 reports the number of Chinese exporters (excluding wholesalers) present in all world markets, and in the RASFF market. For clarity, the statistics are reported every two years. On average, between $24 \%$ and $32 \%$ of Chinese exporters are present in the RASFF market. The number of active exporters rose between 2001 and 2007 and after 2009, with a small drop in export activity during the 2008-2009 crisis. The sample of products exported over time is relatively stable, with a decrease after 2007. Contrary to the number of exporters, no further increase is observed at the end of the crisis. Many exporters to the RASFF market are singleproduct firms. On average, firms export 1.6 products to the RASFF market (the median is equal to 1). Figure 1 plots Chinese agri-food exports (in logs) over the sample period. World exports and flows to the RASFF market are represented. In line with the growth in the number of exporting firms, exports tend also to increase over the period (except in 2009).

Insert Table 2 and Figure 1 here

Figure 2 provides statistics related to RASFF rejections for all shipments regardless of origin. ${ }^{19}$ A significant rise in the number of RASFF rejections between 2000 and 2003 is depicted in panel (1). This increase primarily reflects growing attention to sanitary risks (e.g. bovine spongiform encephalopathy, dioxins, and mycotoxins) and increased application of the system by RASFF members. Since 2003, the number of rejections annually was between 1,000 and 1,500 annually, with significant decreases in 2006 and 2007 not driven either by the change in RASFF members or the moving EU border. Our country of interest, China, is one of the countries most affected by RASFF rejections (panel (2)). ${ }^{20}$

Figure 3 reports the number of RASFF rejections affecting Chinese shipments (panel (1)) and the main HS2 sectors affected by rejections (panel (2)). There is an increasing trend in rejections of Chinese shipments over time (with a dip in 2009 related to the crisis) suggesting a positive correlation between Chinese exports (see Figure 1) and Chinese rejections at the RASFF border. Also, we observe a strong increase in the number of rejections in 2008 which might suggest that at the beginning of the 2008-2009 crisis, inspections and rejections were used potentially in a protectionist way, i.e. to protect European producers from Chinese competition. In our empirical analysis, we include sector-time fixed effects to control for this increasing trend. Panel (2) shows that oil seeds (HS12) and fish and fishery products (HSO3) are the Chinese sectors most affected by rejections, accounting for more than $60 \%$ of all rejections. The very high share of sector HS12 in Chinese rejections relates to mycotoxin problems in peanuts (HS1202).

\section{Insert Figure 2 and Figure 3 here}

\footnotetext{
${ }^{19}$ We focus on the period 2000-2011, which is the one covered by Chinese customs data. Few rejections (less than 5\%) occurred between 1979 and 1999.

${ }^{20}$ Turkey and Iran are ranked among the top rejected origin countries. Mycotoxins are a well known issue of Turkish exports of pistachios and dried figs, and Iranian pistachios. All Iranian exports of pistachios are double checked for freedom from mycotoxins.
} 
Figure 4 shows whether there is some hysteresis driving RASFF rejections. It plots simple correlations of the data, comparing current and lagged rejections (in $t-1$ ) at the same country-HS4 product dimension, for all countries (panel (1)), and for China (panel (2)). Lagged rejections are represented on the $y$-axis, and current ones on the $x$-axis. Figure 4 provides descriptive evidence of positive correlations. It also highlights that inspections (and therefore rejections) clearly are not random but are driven largely by past rejections. Of course, this analysis is based on simple correlations and does not control for sector and exporter characteristics.

Insert Figure 4 here

\section{Empirical strategy}

We investigate the trade impact of RASFF border rejections on Chinese firms. As discussed above, border inspections and possible rejections create some uncertainty and have an impact on exports. Furthermore, this impact is likely to be heterogeneous across exporters. First, not all shipments are inspected and inspections are not random. Certain firms or products, presenting higher safety risks, tend to attract particular scrutiny. Second, some exporters, especially the biggest and most productive ones, are more able to invest in maintaining the quality of their products or in controls prior to shipment, thus reducing their risk of rejections.

Although the RASFF data do not allow direct identification of the shipment and exporting firms hit by a rejection, we can estimate the effect of a rejection of a particular product on all exporters of that product. Our empirical analysis is aimed at estimating exporter behaviors at the extensive and intensive margins of trade as a function of rejection measures and their effect jointly with firm characteristics. We follow the empirical strategy suggested by Fontagné et al. (2015) and estimate the following equation:

$$
\begin{array}{r}
\left.y_{i, s, t}=\alpha+\beta_{1} \text { rejection }_{s, t-1}+\beta_{2} \ln (\text { size })_{i, t-1}+\beta_{3} \text { rejection }_{s, t-1} \times \ln (\text { size })_{i, t-1}\right] \\
+\mu_{i}+\phi_{H S 2, t}+\epsilon_{i, s, t},
\end{array}
$$

where $i$ refers to the firm, $s$ to the HS4-digit product category, and $t$ to the year.

As already mentioned, the RASFF border is the relevant location for our study. Since RASFF countries exchange information on rejections, one product rejected at one RASFF border will not be able to enter the RASFF market via another border. Therefore, we do not consider export flows to each RASFF country separately, but aggregate exports to all RASFF countries. Thus, the RASFF market as a whole is the only destination in our analysis. The aggregation of all RASFF countries into a single destination presents another advantage. A product could be rejected by a country which is not its final destination. However, Chinese customs data report only final destinations. This divergence between the final destination and the country of rejection could bias the results of an analysis conducted at the country-level. Aggregation at the RASFF market level addresses this issue. 
Considering the RASFF market as a whole does not allow us to properly control for tariff protection. However, in our analysis, this is not a major issue. All importing countries (except Iceland, Liechtenstein, and Norway) are part of the EU and apply the same common external tariffs. Therefore, tariffs are almost invariant across RASFF countries. Also, the tariffs imposed by RASFF countries on Chinese products did not vary significantly between 2000 and 2011, and a large part of any variation is captured by the set of sector-year fixed effects included in our estimations (cf. infra). Therefore, the absence of a control for tariffs does not bias our results.

We define three dependent variables, $y_{i, s, t}$ :

- A dummy for exit that equals 1 if the firm exports the HS4 product to the RASFF market in $t-1$ but not in $t$ ( 0 otherwise). The counterfactual is firms that export a given HS4 to RASFF countries in $t-1$ and also in $t$. We disregard re-entry in later periods;

- A dummy for entry that equals 1 if the firm exports the HS4 product to the RASFF market in $t$ but not in $t-1$ ( 0 otherwise). Here, the counterfactual is firms that do not enter the market, i.e. do not export a given HS4 to RASFF countries in $t-1$ or in $t$.

The entry and exit variables capture the (firm-HS4) extensive margin of trade. They are not analogous. As highlighted by the counterfactual, exit is conditional on the firm being active in $t-1$, while entry is conditional on not exporting in $t-1$.

- The value of the export flows for the intensive margin - specifically, the value exported by the firm to the RASFF market for a given HS4 product in year $t$. We focus on incumbents (surviving firms, i.e. firms that are already present in $t-1$ and continue to export in year $t$. In other words, we do not consider firms that start to export in year $t$.)

Our set of explanatory variables includes border rejections and firm characteristics. We consider two different measures for border rejections. As suggested by Essaji (2008), we use lagged rejections as internal instruments (i.e. before actual exports in $t$ ). Our rejection measures (rejection $\left._{s, t-1}\right)$ are:

- A dummy for past rejections that equals 1 if at least one shipment from China of that particular HS4 product was rejected at the RASFF border in $t-1$ (0 otherwise);

- The cumulated number of past rejections from China for that HS4 product. This cumulated number is computed simply as the sum of Chinese shipments of that particular HS4 product which were rejected in the past (i.e. from 1979 until year $t-1$ ).

The trade literature (Melitz, 2003) highlights that firms' export performance is heterogeneous and driven largely by their productivity. Unfortunately, Chinese customs data do not provide details on firms' characteristics (e.g. productivity, employment, total sales, etc.). Thus, to control for firm heterogeneity and its impact on export performance, we refer to firm size, defined as the log of their total agri-food exports in $t-1\left(\ln (\operatorname{size})_{i, t-1}\right)$. As shown in the literature (Mayer and Ottaviano, 2008), export values are a good proxy for firm size, and big 
exporters are usually more efficient and more productive. For ease of interpretation, we center firm size around the median size of all firms in that year.

To capture some heterogeneous effects on the impact of rejections across firms, we interact our rejection variables (dummy and cumulated number) with firm size.

Finally, we include fixed effects to control for unobserved heterogeneity. We introduce HS2 sector-year $\left(\phi_{H S 2, t}\right)$ and firm $\left(\mu_{i}\right)$ fixed effects. These fixed effects control respectively for business cycles and import-demand shocks at the sector level, and for time-invariant characteristics specific to a firm such as productivity or average size.

We do not cluster the standard errors. Our main variable of interest is the interaction term between rejections and firm size. This variable varies at the firm-HS4-year level, negating the need to cluster. ${ }^{21}$

We estimate all equations by ordinary least squares (OLS). The extensive margin dependent variables are dichotomous in nature. However, we prefer the linear probability model (LPM) to non-linear models such as logit or probit since LPM avoids the incidental parameter problem in the presence of the large number of fixed effects we employ. Furthermore, OLS allows simple interpretation of sample average marginal effects.

Throughout we exclude wholesalers from our estimations; as already mentioned, we want to focus on the firm's decisions. However, we conduct a series of robustness checks with wholesalers; our main conclusions remain unchanged (cf. infra).

\section{Results}

First, we study whether rejections of Chinese shipments affect Chinese exports to the RASFF market. The analysis is performed at both the extensive and intensive margins of trade. We then test the robustness of our results.

\subsection{Extensive margin of trade}

The first three columns in Table 3 present the impact of Chinese rejections on the exit of Chinese firms from the RASFF market. In columns (1) and (2), rejections are measured using a dummy that is set to 1 if at least one shipment of the same HS4 was rejected in $t-1$. We investigate exit in year $t$. Column (3) reports the cumulated number of past rejections of Chinese shipments for that HS4 over time until $t-1$. In all columns we control for firm size. Columns (2) and (3) also include an interaction term between firm size and past rejections. The results suggest that when we control for heterogeneity in the impact of rejections across firms, past rejections increase the probability of exit of Chinese firms from the RASFF market. According to column

\footnotetext{
${ }^{21}$ We conduct a robustness check with clustered standard errors (cf. infra); the results remain unchanged.
} 
(3), past rejections raise the probability of exit by $4.8 \%$. In addition, exit affects small and less productive firms more than big firms; the estimated coefficient of the interaction term between firm size and rejections is negative. In line with the large literature on firm-level exports, we find also that - everything else being equal, i.e. regardless of past border rejections - small firms tend to exit more.

Columns(4)-(6) in Table 3 report the impact of Chinese rejections on the entry of Chinese firms into the RASFF market. The estimations include the same explanatory variables as in columns (1)-(3). We find that rejections tend to favor the entry of new firms. The estimated coefficients on both rejection measures (dummy and cumulated number) are positive and significant ( $p<$ 0.01 ). The magnitude of the effects is between $0.8 \%$ (column (3)) and $1.1 \%$ (column (2)) depending on the measure used for rejections. Also, it seems that rejections promote the entry of small firms more than big firms; the estimated coefficient of the interaction term between firm size and rejections is negative and significant $(p<0.01)$. Finally, regardless of past rejections, big and productive firms enter the RASFF market more easily than small ones. Comparison of estimated coefficients of the exit and entry probability reveals that past rejections have a much stronger impact on firm exit than on firm entry. The $R^{2}$ are also significantly lower in columns (4)-(6).

Overall, our results are in line with Jaud et al. (2013), who find that sanitary risk increases the diversification of European imports at the extensive margin. Here, we observe turnover among Chinese firms exporting to the RASFF market. Past rejections increase both the exit of Chinese exporters and the entry of new ones, and the effect on both exit and entry is stronger for small firms.

The last column in Table 3 rather than examining exit and entry probabilities, aggregates the observations at the HS4 sector-year level and considers the (log) number of Chinese firms exporting to the RASFF market. Interestingly, the estimated coefficient of the cumulated number of past rejections is negative and significant $(p<0.10)$, suggesting that exit tends to dominate entry. Border rejections reduce the total number of Chinese firms exporting to the RASFF market. Also, the number of small firms shows a bigger decrease compared to big firms, and the estimated coefficient of the interaction with firm size is positive and strongly significant. Finally, as expected, the presence in the market of big firms in the past has a negative effect on the number of firms currently in the market.

Insert Table 3 here

\subsection{Intensive margin of trade}

Next, we focus on the intensive margin of trade (Table 4). Columns (1)-(3) look at the value exported by incumbent firms (i.e. firms present in years $t-1$ and $t$ ) to the RASFF market. Our results highlight three main facts. First and independent of border rejections, bigger firms tend to survive and increase their exports to the RASFF market (the variable for firm size is 
significant, with $p<0.01$ ). Second, on average firms that continue exporting products hit by rejections neither increase nor decrease their exports to the RASFF market. The two variables (dummy and cumulated number of past rejections) have no significant impact on the export values in columns (2) and (3). Third, some heterogeneity is observable across firms, and the results for the interaction terms between past rejections and firm size suggest that big and more productive incumbent firms increase their exports to the RASFF market in the year(s) following a rejection. Therefore, large firms do benefit from the exit of small exporters consecutive with a rejection.

Column (4) investigates the impact of border rejections on the quantity exported by incumbents, while column (5) examines the price - measured as the unit value - of the products exported by these firms. ${ }^{22}$ The heterogeneous effect of past rejections across firms remains positive but is less significant ( $p<0.05$ for quantity and $p<0.10$ for price). In terms of magnitude the effect on price is smaller than the effect on quantity. Finally regardless of past rejections, firm size has no impact on price. These results suggest that big and productive incumbent firms increase the quantity exported to the RASFF market, and also but to a lesser extent the product price.

Our results at the intensive margin show some concentration of Chinese exports among big and productive exporters. The effect is stronger for products hit by past rejections. These results confirm Jaud et al. (2013), who also highlight concentration at the intensive margin, especially for risky products. When rejections are more frequent and cumulate, European importers concentrate their orders on large, and plausibly more reliable Chinese exporters, who increase their exports to the RASFF market.

\section{Insert Table 4 here}

Thus, on the global impact of rejections on the exports of Chinese firms to the RASFF market, we observe two effects: some turnover of firms at the extensive margin of trade, accompanied by some level of concentration at the intensive margin.

\subsection{Robustness checks}

In this section, we investigate the robustness of our results to alternative specifications and samples. All the tests are performed using our preferred estimations, i.e. those including the cumulated number of past rejections as a measure of border rejections, and the interaction term between this rejection measure and firm size. Three estimations are run in each case: one for the probability that the Chinese firms will exit the RASFF market, one for the probability of entry into that market, and one for the intensive margin of trade.

First, we test whether our results change if the standard errors are clustered. As mentioned in Section 4, clustering is not mandatory in our case because our variable of interest (i.e. the

\footnotetext{
${ }^{22}$ Some prices exhibit extreme values. We exclude these outliers by deleting the top and bottom $1 \%$ of the price observations.
} 
interaction term between rejections and firm size) varies at the firm-HS4-year level. However as a robustness check, columns (1)-(3) in Table 5 include clusters defined at the HS4-year level. The results are not affected by their inclusion.

A second source of potential bias relates to churning flows and potential reverse causality. To check for this, we introduce in the estimation a measure of the mean length of HS4 flows exported to the RASFF market (columns (4)-(6) in Table 5). This variable has a significant influence on both the extensive and intensive trade margins but its inclusion does not affect our previous conclusions.

Insert Table 5 here

Endogeneity may stem also from our focus on Chinese rejections and Chinese firms' exports. Potential bias is reduced by the use of lagged rejections. In addition, below, we replicate our main estimations using two alternative sets of rejections: i) non-Chinese rejections, ii) all rejections whatever the product origin (i.e. Chinese and non-Chinese). Table 6 reports the results. For the extensive margin of trade, the magnitude of the estimated coefficients is lower, but they have the same sign and level of significance as in Table 3. This suggests that rejections related to products imported into Europe from non-Chinese suppliers but also exported by Chinese firms shape the participation of Chinese firms. The occurrence of rejections for a given product category increases the probability of additional controls on similar products from all origins, which curbs Chinese export participation, although the impact is weaker compared to the effect of rejections of Chinese products. Chinese exporters fear tighter controls on the type of products they export, even if these controls do not necessarily target their own flows. Results at the intensive margin of trade first confirm the expected market shares redistribution. Chinese firms substitute at least partially for competitors following rejection of non-Chinese products: the estimated coefficient of the cumulated number of past rejections becomes significant at the intensive margin. Second, we cannot reject the hypothesis that Chinese firms benefit equally, whatever their size, from this redistribution of market shares: the heterogeneous effect of past rejections on small vs. big and productive firms disappears, since the estimated coefficient of the interaction terms is not significant at the intensive margin.

Insert Table 6 here

A potential issue raised by the previous estimations is the "sensitivity" of exported products to control. For instance, among oilseeds certain product categories (e.g. peanuts) are highly sensitive to mycotoxins and should be more often subjected to control at the RASFF borders. This outcome is not captured by our previous set of fixed effects. We control for the timeinvariant characteristics of products by introducing HS4 fixed effects. This strategy allows us to disentangle the product-country vs. product only dimensions related to inspections. The first three columns in Table 7 control for these product (unobservable) characteristics. At the extensive margin of trade, our previous results remain unchanged. At the intensive margin, the estimated coefficient of the border rejection variable becomes negative and significant ( $p<$ 
0.01), suggesting that firms export less of HS4 products hit by rejections if we control for unobserved characteristics. Even for big firms the effect is negative; the sum of the coefficients of the cumulated number of past rejections and of the interaction term is negative. Our results suggest also that the negative externalities induced by border rejections have a mainly productcountry rather than a product-only dimension. In other words, Chinese exporters are affected negatively by rejections affecting the same Chinese product as the one they export. This is in line with the results in columns (3) and (6) in Table 6. At the intensive margin, Chinese exporters seem to benefit from rejections affecting non-Chinese products but are negatively affected by rejections targeting Chinese products.

The last three columns in Table 7 account for the intensity of Chinese export flows to the RASFF market for each HS4 sector. The number of rejections affecting Chinese shipments varies across sectors (see panel (2) of Figure 3). Part of this variation is due to the sanitary risk which of course might differ across products, but part comes from the intensity of trade between China and RASFF countries. A sector characterized by many flows is likely - all else being equal - to encounter a higher number of rejections. To control for the intensity of trade, we weight the cumulated number of past rejections by the cumulated number of past export flows, computed as the cumulated number of export flows by Chinese firms to RASFF countries within one HS4 sector over time. The results confirm, and even strengthen our previous findings since the magnitude of estimated coefficients is stronger than those reported in Tables 3 and 4.

\section{Insert Table 7 here}

Next, we test whether our results are sensitive to the sample of firms considered in the estimations. ${ }^{23}$ First, we exclude firms exporting to the RASFF market only over a short period. To do so, we compute the number of years of presence of each Chinese firm exporting to the RASFF market. We then restrict our sample to firms where the number of years of presence is above the median. The first three columns in Table 8 present the results of these estimations. The sample restriction has no impact on our previous conclusions. The three last columns in Table 8 add wholesalers to the sample of firms. So far, our analysis has been restricted to non-wholesalers in order to examine active firm export decisions. However, wholesalers represent a non-negligible number of Chinese exporters. In fact, their inclusion in the sample has almost no impact on the estimated coefficients, and the previous findings remain valid.

\section{Insert Table 8 here}

Firms exporting to other OECD markets (i.e. Australia, Canada, Japan, New Zealand, Switzerland, South Korea, and the US) may be more successful in passing RASFF inspections. Other OECD markets also impose stringent safety regulations, and conduct inspections. Therefore, firms exporting to these markets are more likely to sell safe products and to have higher productivity which may help them to deal with inspections and their related costs and uncertainty.

\footnotetext{
${ }^{23}$ Unfortunately, information on ownership is missing for many firms. Therefore, we cannot test whether rejections have a differentiated impact on foreign, private, and state-owned firms.
} 
Table 9 distinguishes between firms exporting to at least one OECD market (other than the RASFF market) in $t-1$ vs. other firms, and investigates whether rejections have different trade effects on these two groups of firms. We first observe that our previous conclusions diversification at the extensive margin and concentration at the intensive one - are accurate for both groups of firms. However, there are some differences in the magnitude of the estimated coefficients. Exit from the RASFF market due to border rejections is less likely for firms already exporting to another OECD market in $t-1$. In addition, this effect is magnified for big and productive firms (columns (1) and (2)). Also, entry to the RASFF market induced by rejections is slightly stronger for firms already exporting to at least one other OECD market (columns (3) and (4)). At the intensive trade margin, productive incumbent firms exporting to OECD markets in $t-1$ are also more likely to increase their exports to the RASFF market in $t$ compared to other firms (columns (5) and (6)).

Insert Table 9 here

\section{Concluding Remarks}

In this paper, we were interested in whether a rise in uncertainty related to the risk of border rejections affects imports from a large developing economy (e.g. China). If border rejections result in an increased focus and increased likelihood of inspection, a series of import refusals could induce negative spillovers for competitors from the same origin and/or exporting the same product.

Our results show that Chinese exporters of agri-food products are more likely to exit the European market if the product they export has been rejected in previous years. At the same time, rejections favor the entry of new firms. This highlights some diversification effect at the extensive margin of trade. At the intensive margin, border rejections boost the exports of incumbent firms, suggesting some concentration effect. Furthermore, the microeconomic impact of the risk of rejection is heterogeneous across firms. Turnover at the extensive margin mainly concerns small firms, while concentration at the intensive margin benefits big firms more. Overall, the number of firms tends to decrease but the size of the surviving firms increases. Our results confirm the key role played by uncertainty, and that big and more productive firms are more resilient than small ones to the risk of border rejections.

Our results contribute to the large literature on firm heterogeneity and trade. We provide a more nuanced understanding of the impact of de facto restrictive regulations on exporting firms. Furthermore given the importance of food safety and importers' emphasis on sourcing from reliable producers, our results suggest that policy makers and law enforcers should adopt a comprehensive approach and pay attention to individual firms while focusing on whole sectors. 


\section{References}

Acemoglu, D. and Robinson, J. A. (2006). De facto political power and institutional persistence. American Economic Association Papers and Proceedings, 96(2):325-330.

Baylis, K., Martens, A., and Nogueira, L. (2009). What drives import refusals. American Journal of Agricultural Economics, 91(5):1477-1483.

Baylis, K., Nogueira, L., and Pace, K. (2011). Food import refusals: Evidence from the european union. American Journal of Agricultural Economics, 93(2):566-572.

Caballero, R. J. and Corbo, V. (1989). The effect of real exchange rate uncertainty on exports: Empirical evidence. The World Bank Economic Review, 3(2):263-278.

Chen, N. and Novy, D. (2012). On the measurement of trade costs: direct vs. indirect approaches to quantifying standards and technical regulations. World Trade Review, 11(3):401414.

Disdier, A.-C., Fontagné, L., and Mimouni, M. (2008). The impact of regulations on agricultural trade: Evidence from the sps and tbt agreements. American Journal of Agricultural Economics, 90(2):336-350.

Essaji, A. (2008). Technical regulations and specialization in international trade. Journal of International Economics, 76(2):166-176.

Falvey, R. E. (1989). Trade, quality reputations and commercial policy. International Economic Review, (3):607-622.

Feng, L., Li, Z., and Swenson, D. L. (2014). Trade policy uncertainty and exports: Evidence from china's wto accession. CESifo Working Paper Series, 4780.

Fontagné, L., Orefice, G., Piermartini, R., and Rocha, N. (2015). Product standards and margins of trade: Firm level evidence. Journal of international economics, 97(1):29-44.

Francois, J. F. and Martin, W. (2004). Commercial policy variability, bindings, and market access. European Economic Review, 48(3):665-679.

Freund, C. L. and Rocha, N. (2011). What constrains africa's exports? The World Bank Economic Review, 25(3):361-386.

Grobar, L. M. (1993). The effect of real exchange rate uncertainty on Idc manufactured exports. Journal of Development Economics, 41(2):367-376.

Grundke, R. and Moser, C. (2014). Hidden protectionism? evidence from non-tariff barriers to trade in the united states. , ETH Zurich KOF Working Papers, 369.

Guimbard, H., Jean, S., Mimouni, M., and Pichot, X. (2012). Macmap-hs6 2007, an exhaustive and consistent measure of applied protection in 2007. International Economics, 130(2):99121.

Handley, K. (2014). Exporting under trade policy uncertainty: Theory and evidence. Journal of International Economics, 94(1):50-66.

Héricourt, J. and Poncet, S. (2015). Exchange rate volatility, financial constraints, and trade: 
Empirical evidence from chinese firms. The World Bank Economic Review, 29(3):550-578.

Hooper, P. and Kohlhagen, S. W. (1978). The effect of exchange rate uncertainty on the prices and volume of international trade. Journal of International Economics, 8(4):483-511.

Jaud, M., Cadot, O., and Suwa-Eisenmann, A. (2013). Do food scares explain supplier concentration? an analysis of eu agri-food imports. European Review of Agricultural Economics, 40(5):873-890.

Jouanjean, M.-A., Maur, J.-C., and Shepherd, B. (2015). Reputation matters: Spillover effects for developing countries in the enforcement of us food safety measures. Food Policy, 55:8191.

Kee, H. L., Nicita, A., and Olarreaga, M. (2009). Estimating trade restrictiveness indices. Economic Journal, 119(534):172-199.

Mayer, T. and Ottaviano, G. (2008). The happy few: The internationalisation of european firms. Intereconomics: Review of European Economic Policy, 43(3):135-148.

McQuade, T. J., Salant, S. W., and Winfree, J. A. (2012). Markets with untraceable goods of unknown quality: Beyond the small-country case. Resources for the Future Discussion Paper, 09-31-rev.

Melitz, M. J. (2003). The impact of trade on intra-industry reallocations and aggregate industry productivity. Econometrica, 71(6):1695-1725.

Nordås, H. K. and Piermartini, R. (2004). Infrastructure and trade. WTO Staff Working Paper, No. ERSD-2004-04.

Osnago, A., Piermartini, R., and Rocha, N. (2015). Trade policy uncertainty as barrier to trade. WTO Staff Working Paper, ERSD-2015-05.

Shapiro, C. (1983). Premiums for high quality products as returns to reputations. The Quarterly Journal of Economics, 98(4):659-680. 
Table 1 - RASFF members

\begin{tabular}{|c|c|c|c|c|}
\hline \multicolumn{2}{|c|}{ Since 1995} & \multicolumn{2}{|c|}{ from 2004} & \multirow{2}{*}{$\frac{\text { from } 2007}{\text { Bulgaria }}$} \\
\hline Austria & Italy & Cyprus & Lithuania & \\
\hline Belgium & Liechtenstein* & Czech Rep. & Malta & Romania \\
\hline Denmark & Luxembourg & Estonia & Poland & \\
\hline Finland & Netherlands & Hungary & Slovenia & \\
\hline France & Norway* & Latvia & Slovakia & \\
\hline Germany & Portugal & & & \\
\hline Greece & Spain & & & \\
\hline Iceland* & Sweden & & & \\
\hline Ireland & United Kingdom & & & \\
\hline
\end{tabular}

Table 2 - Chinese firms: descriptive statistics

\begin{tabular}{|c|c|c|c|c|c|c|}
\hline & 2001 & 2003 & 2005 & 2007 & 2009 & 2011 \\
\hline \multicolumn{7}{|l|}{ World agri-food exports } \\
\hline $\mathrm{Nb}$. of firms & 7340 & 8834 & 12321 & 12259 & 11314 & 11604 \\
\hline $\mathrm{Nb}$. of HS4 products & 192 & 195 & 196 & 192 & 185 & 185 \\
\hline \multicolumn{7}{|l|}{ Agri-food exports to RASFF market } \\
\hline $\mathrm{Nb}$. of firms & 1800 & 2083 & 3176 & 3604 & 3548 & 3730 \\
\hline $\mathrm{Nb}$. of HS4 products & 137 & 135 & 150 & 151 & 140 & 136 \\
\hline \multirow[t]{2}{*}{$\mathrm{Nb}$. of HS4 products per firm } & 1.68 & 1.57 & 1.64 & 1.68 & 1.61 & 1.59 \\
\hline & 1 & 1 & 1 & 1 & 1 & 1 \\
\hline
\end{tabular}

Note: Authors' computation. These statistics exclude wholesalers. 
Table 3 - Extensive-margin estimations

\begin{tabular}{|c|c|c|c|c|c|c|c|}
\hline & \multicolumn{3}{|c|}{$\begin{array}{c}\text { Exit from the RASFF } \\
\text { market in year } t\end{array}$} & \multicolumn{3}{|c|}{$\begin{array}{c}\text { Entry in the RASFF } \\
\text { market in year } t\end{array}$} & \multirow{2}{*}{$\begin{array}{c}\text { Log number } \\
\text { of firms } \\
\text { (7) }\end{array}$} \\
\hline & $(1)$ & (2) & (3) & (4) & (5) & (6) & \\
\hline Dummy $=1$ if at least one rejection in $t-1$ & $\begin{array}{l}-0.026^{a} \\
(0.007)\end{array}$ & $\begin{array}{c}0.124^{a} \\
(0.031)\end{array}$ & & $\begin{array}{c}0.006^{b} \\
(0.003)\end{array}$ & $\begin{array}{c}0.011^{a} \\
(0.003)\end{array}$ & & \\
\hline Dummy for rejection in $t-1 \mathrm{X}$ Firm size & & $\begin{array}{l}-0.012^{a} \\
(0.002)\end{array}$ & & & $\begin{array}{c}-0.002^{a} \\
(0.0004)\end{array}$ & & \\
\hline Cumulated nb. of past rejections until $t-1$ & & & $\begin{array}{c}0.048^{a} \\
(0.012)\end{array}$ & & & $\begin{array}{c}0.008^{a} \\
(0.001)\end{array}$ & $\begin{array}{l}-0.138^{c} \\
(0.072)\end{array}$ \\
\hline Cum. nb. past rejections $X$ Firm size & & & $\begin{array}{l}-0.005^{a} \\
(0.001)\end{array}$ & & & $\begin{array}{l}-0.001^{a} \\
(0.0001)\end{array}$ & $\begin{array}{c}0.017^{a} \\
(0.006)\end{array}$ \\
\hline Firm size & $\begin{array}{c}-0.0047^{a} \\
(0.002)\end{array}$ & $\begin{array}{l}-0.043^{a} \\
(0.002)\end{array}$ & $\begin{array}{l}-0.041^{a} \\
(0.002)\end{array}$ & $\begin{array}{c}0.013^{a} \\
(0.0002) \\
\end{array}$ & $\begin{array}{c}0.013^{a} \\
(0.0002) \\
\end{array}$ & $\begin{array}{c}0.014^{a} \\
(0.0003)\end{array}$ & $\begin{array}{l}-0.010^{b} \\
(0.005)\end{array}$ \\
\hline Observations & 49220 & 49220 & 49220 & 178951 & 178951 & 178951 & 1542 \\
\hline$R^{2}$ & 0.391 & 0.391 & 0.392 & 0.081 & 0.081 & 0.082 & 0.951 \\
\hline
\end{tabular}

Note: Fixed effects for firms and HS2-year in columns (1)-(6) and for HS4 sectors and HS2-year in column (7) (not reported). Robust standard errors in parentheses. Columns (1)-(3): Exit-probabilities. Columns (4)-(6): Entry-probabilities. Column (7): Number of firms. ${ }^{a}: p<0.01,{ }^{b}$ : $p<0.05,{ }^{c}: p<0.10$.

\section{Table 4 - Intensive-margin estimations}

\begin{tabular}{|c|c|c|c|c|c|}
\hline & \multicolumn{5}{|c|}{$\begin{array}{l}\text { Ln exports to the RASFF market in } t \\
\text { (Incumbent firms) }\end{array}$} \\
\hline & (1) & $\begin{array}{l}\text { Value } \\
\text { (2) }\end{array}$ & (3) & $\begin{array}{c}\text { Quan- } \\
\text { tity } \\
(4)\end{array}$ & $\begin{array}{c}\text { Unit } \\
\text { value } \\
(5)\end{array}$ \\
\hline Dummy $=1$ if at least one rejection in $t-1$ & $\begin{array}{c}0.269^{a} \\
(0.031)\end{array}$ & $\begin{array}{c}-0.193 \\
(0.165)\end{array}$ & & & \\
\hline Dummy for rejection in $t-1 \times$ Firm size & & $\begin{array}{c}0.035^{a} \\
(0.012)\end{array}$ & & & \\
\hline Cumulated nb. of past rejections until $t-1$ & & & $\begin{array}{l}-0.010 \\
(0.067)\end{array}$ & $\begin{array}{c}-0.007 \\
(0.070)\end{array}$ & $\begin{array}{c}-0.002 \\
(0.027)\end{array}$ \\
\hline Cum. nb. past rejections $X$ Firm size & & & $\begin{array}{c}0.014^{a} \\
(0.005)\end{array}$ & $\begin{array}{c}0.010^{b} \\
(0.005)\end{array}$ & $\begin{array}{c}0.003^{c} \\
(0.002)\end{array}$ \\
\hline Firm size & $\begin{array}{c}0.163^{a} \\
(0.010)\end{array}$ & $\begin{array}{c}0.151^{a} \\
(0.011)\end{array}$ & $\begin{array}{c}0.149^{a} \\
(0.012)\end{array}$ & $\begin{array}{c}0.141^{a} \\
(0.012)\end{array}$ & $\begin{array}{c}0.008^{c} \\
(0.005)\end{array}$ \\
\hline Observations & 30999 & 30999 & 30999 & 30982 & 30486 \\
\hline$R^{2}$ & 0.623 & 0.623 & 0.625 & 0.651 & 0.788 \\
\hline
\end{tabular}

Note: Fixed effects for firms and HS2-year in all estimations (not reported). Robust standard errors in parentheses.

a: $\mathrm{p}<0.01, \quad$ : $: \mathrm{p}<0.05,{ }^{c}: \mathrm{p}<0.1$. 
Table 5 - Robustness: clustering and churning flows

\begin{tabular}{lcccccc}
\hline & \multicolumn{3}{c}{ With clusters } & \multicolumn{3}{c}{ Churning flows } \\
& Exit & Entry & IM & Exit & Entry & IM \\
& $(1)$ & $(2)$ & $(3)$ & $(4)$ & $(5)$ & $(6)$ \\
\hline Cum. nb. of past rej. until $t-1$ & $0.048^{a}$ & $0.008^{a}$ & -0.010 & $0.065^{a}$ & $0.007^{a}$ & -0.107 \\
& $(0.013)$ & $(0.001)$ & $(0.085)$ & $(0.012)$ & $(0.001)$ & $(0.066)$ \\
Cum. nb. past rej. X Firm size & $-0.005^{a}$ & $-0.001^{a}$ & $0.014^{b}$ & $-0.006^{a}$ & $-0.001^{a}$ & $0.016^{a}$ \\
& $(0.001)$ & $(0.0001)$ & $(0.006)$ & $(0.001)$ & $(0.0001)$ & $(0.005)$ \\
Firm size & $-0.041^{a}$ & $0.014^{a}$ & $0.149^{a}$ & $-0.041^{a}$ & $0.014^{a}$ & $0.149^{a}$ \\
& $(0.002)$ & $(0.0003)$ & $(0.013)$ & $(0.002)$ & $(0.0003)$ & $(0.012)$ \\
Mean length of flows & & & & $-0.271^{a}$ & $0.042^{a}$ & $1.566^{a}$ \\
& & & & $(0.009)$ & $(0.004)$ & $(0.048)$ \\
\hline Observations & & & & & & \\
$R^{2}$ & 49220 & 178951 & 30999 & 49220 & 178951 & 30999 \\
\hline Note: Fixed & 0.392 & 0.082 & 0.625 & 0.405 & 0.042 & 0.640 \\
\hline
\end{tabular}

Note: Fixed effects for firms and HS2-year in all estimations (not reported). Robust standard errors in parentheses. Columns (1)-(3): Standard errors in parentheses, clustered at HS4-year level. Columns (4)-(6): Regressions also include the mean length of flows. ${ }^{a}: \mathrm{p}<0.01,{ }^{b}: \mathrm{p}<0.05$

Table 6 - Robustness: Non-Chinese and whole sample of rejections

\begin{tabular}{lccccccc}
\hline & \multicolumn{3}{c}{ Non-Chinese rejections } & \multicolumn{3}{c}{ All rejections } \\
& Exit & Entry & IM & Exit & Entry & IM \\
& $(1)$ & $(2)$ & $(3)$ & $(4)$ & $(5)$ & $(6)$ \\
\hline Cum. nb. of past rej. until $t-1$ & $0.024^{a}$ & $0.005^{a}$ & $0.116^{b}$ & $0.024^{a}$ & $0.005^{a}$ & $0.117^{b}$ \\
& $(0.008)$ & $(0.001)$ & $(0.049)$ & $(0.008)$ & $(0.001)$ & $(0.047)$ \\
Cum. nb. past rej. X Firm size & $-0.002^{a}$ & $-0.001^{a}$ & -0.004 & $-0.002^{a}$ & $-0.001^{a}$ & -0.004 \\
& $(0.001)$ & $(0.0001)$ & $(0.003)$ & $(0.001)$ & $(0.0001)$ & $(0.003)$ \\
Firm size & $-0.042^{a}$ & $0.014^{a}$ & $0.171^{a}$ & $-0.042^{a}$ & $0.015^{a}$ & $0.171^{a}$ \\
& $(0.002)$ & $(0.0003)$ & $(0.013)$ & $(0.002)$ & $(0.0003)$ & $(0.013)$ \\
\hline Observations & 49220 & 178951 & 30999 & 49220 & 178951 & 30999 \\
$R^{2}$ & 0.391 & 0.082 & 0.623 & 0.391 & 0.082 & 0.623 \\
\hline Note: Fixed effects for firms and HS2-year in all estimations (not reported). Robust standard errors in parentheses. \\
Columns (1)-(3): Non-Chinese rejections. Columns (4)-(6): All rejections whatever the origin of the products. ${ }^{a}$ : \\
p<0.01, ${ }^{b}$ : $\mathrm{p}<0.05$.
\end{tabular}

Table 7 - Robustness: HS4 unobservable characteristics and trade flows intensity

\begin{tabular}{lcccccc}
\hline & \multicolumn{3}{c}{ HS4 characteristics } & \multicolumn{3}{c}{ Trade flows intensity } \\
& Exit & Entry & IM & Exit & Entry & IM \\
& $(1)$ & $(2)$ & $(3)$ & $(4)$ & $(5)$ & $(6)$ \\
\hline Cum. nb. of past rej. until $t-1$ & $0.078^{a}$ & $0.004^{b}$ & $-0.159^{b}$ & $0.254^{a}$ & $0.046^{a}$ & 0.077 \\
& $(0.013)$ & $(0.002)$ & $(0.070)$ & $(0.082)$ & $(0.008)$ & $(0.459)$ \\
Cum. nb. past rej. X Firm size & $-0.005^{a}$ & $-0.001^{a}$ & $0.013^{a}$ & $-0.025^{a}$ & $-0.007^{a}$ & $0.057^{b}$ \\
& $(0.001)$ & $(0.0001)$ & $(0.005)$ & $(0.006)$ & $(0.001)$ & $(0.025)$ \\
Firm size & $-0.042^{a}$ & $0.014^{a}$ & $0.152^{a}$ & $-0.043^{a}$ & $0.014^{a}$ & $0.154^{a}$ \\
& $(0.002)$ & $(0.0003)$ & $(0.011)$ & $(0.002)$ & $(0.0003)$ & $(0.012)$ \\
\hline Observations & 49220 & 178951 & 30999 & 49169 & 177252 & 30987 \\
$R^{2}$ & 0.409 & 0.083 & 0.655 & 0.391 & 0.082 & 0.624 \\
\hline
\end{tabular}

Note: Fixed effects for firms and HS2-year in all estimations (not reported). Robust standard errors in parentheses. Columns (1)-(3): Regressions also include HS4 fixed effects (not reported). Columns (4)-(6): Cumulated number of past rejections weighted by the cumulated number of past export flows. ${ }^{a}: \mathrm{p}<0.01,{ }^{b}: \mathrm{p}<0.05$. 
Table 8 - Robustness: firms' number of years of presence and wholesalers

\begin{tabular}{lcccccc}
\hline & \multicolumn{3}{c}{ Above median nb. } & \multicolumn{3}{c}{ With wholesalers } \\
& Exit & Entry & IM & Exit & Entry & IM \\
& $(1)$ & $(2)$ & $(3)$ & $(4)$ & $(5)$ & $(6)$ \\
\hline Cum. nb. of past rej. until $t-1$ & $0.050^{a}$ & $0.009^{a}$ & -0.010 & $0.043^{a}$ & $0.008^{a}$ & -0.039 \\
& $(0.013)$ & $(0.001)$ & $(0.067)$ & $(0.009)$ & $(0.001)$ & $(0.054)$ \\
Cum. nb. past rej. X Firm size & $-0.005^{a}$ & $-0.001^{a}$ & $0.014^{a}$ & $-0.004^{a}$ & $-0.002^{a}$ & $0.016^{a}$ \\
& $(0.001)$ & $(0.0001)$ & $(0.005)$ & $(0.001)$ & $(0.0001)$ & $(0.004)$ \\
Firm size & $-0.041^{a}$ & $0.014^{a}$ & $0.149^{a}$ & $-0.037^{a}$ & $0.015^{a}$ & $0.128^{a}$ \\
& $(0.002)$ & $(0.0003)$ & $(0.012)$ & $(0.002)$ & $(0.0002)$ & $(0.009)$ \\
\hline Observations & 45469 & 133977 & 30999 & 88858 & 352192 & 51998 \\
$R^{2}$ & 0.293 & 0.094 & 0.523 & 0.363 & 0.067 & 0.595 \\
\hline Note: Fixed effects for firms and HS2-year in all estimations (not reported). Robust standard errors in parentheses. \\
Columns (1)-(3): Firms with a number of years of presence above the median. Columns (4)-(6): With wholesalers. \\
a: p<0.01.
\end{tabular}

Table 9 - Robustness: OECD presence in $t-1$

\begin{tabular}{|c|c|c|c|c|c|c|}
\hline & \multicolumn{2}{|c|}{ Exit } & \multicolumn{2}{|c|}{ Entry } & \multicolumn{2}{|c|}{ IM } \\
\hline & $\begin{array}{l}\text { No } \\
(1)\end{array}$ & $\begin{array}{l}\text { Yes } \\
(2)\end{array}$ & $\begin{array}{l}\text { No } \\
(3)\end{array}$ & $\begin{array}{l}\text { Yes } \\
(4)\end{array}$ & $\begin{array}{l}\text { No } \\
(5)\end{array}$ & $\begin{array}{l}\text { Yes } \\
(6)\end{array}$ \\
\hline Cum. nb. of past rej. until $t-1$ & $\begin{array}{c}0.089^{a} \\
(0.030)\end{array}$ & $\begin{array}{l}0.030^{b} \\
(0.014)\end{array}$ & $\begin{array}{l}0.004^{a} \\
(0.001)\end{array}$ & $\begin{array}{c}0.006^{b} \\
(0.003)\end{array}$ & $\begin{array}{l}-0.150 \\
(0.149)\end{array}$ & $\begin{array}{c}0.001 \\
(0.079)\end{array}$ \\
\hline Cum. nb. past rej. X Firm size & $\begin{array}{l}-0.008^{a} \\
(0.002)\end{array}$ & $\begin{array}{l}-0.004^{a} \\
(0.001)\end{array}$ & $\begin{array}{l}-0.001^{a} \\
(0.0003)\end{array}$ & $\begin{array}{l}-0.001^{b} \\
(0.0002)\end{array}$ & $\begin{array}{l}0.024^{b} \\
(0.011)\end{array}$ & $\begin{array}{c}0.013^{b} \\
(0.006)\end{array}$ \\
\hline Firm size & $\begin{array}{l}-0.052^{a} \\
(0.006)\end{array}$ & $\begin{array}{l}-0.036^{a} \\
(0.003)\end{array}$ & $\begin{array}{l}0.013^{a} \\
(0.001)\end{array}$ & $\begin{array}{c}0.006^{a} \\
(0.001)\end{array}$ & $\begin{array}{l}0.089^{a} \\
(0.029)\end{array}$ & $\begin{array}{l}0.153^{a} \\
(0.014)\end{array}$ \\
\hline Observations & 11528 & 37692 & 126216 & 52735 & 6213 & 24786 \\
\hline$R^{2}$ & 0.603 & 0.366 & 0.118 & 0.187 & 0.796 & 0.604 \\
\hline
\end{tabular}


Figure 1 - Chinese agri-food exports between 2000-2011

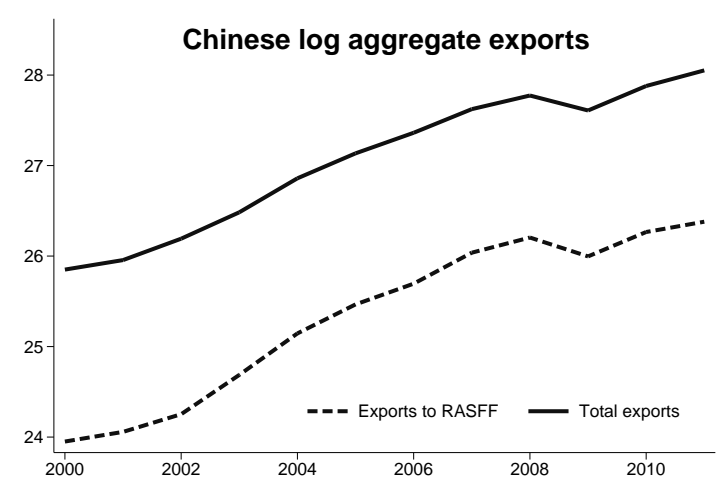

Note: Authors' computation (excluding wholesalers).

Figure 2 - RASFF rejections on all shipments
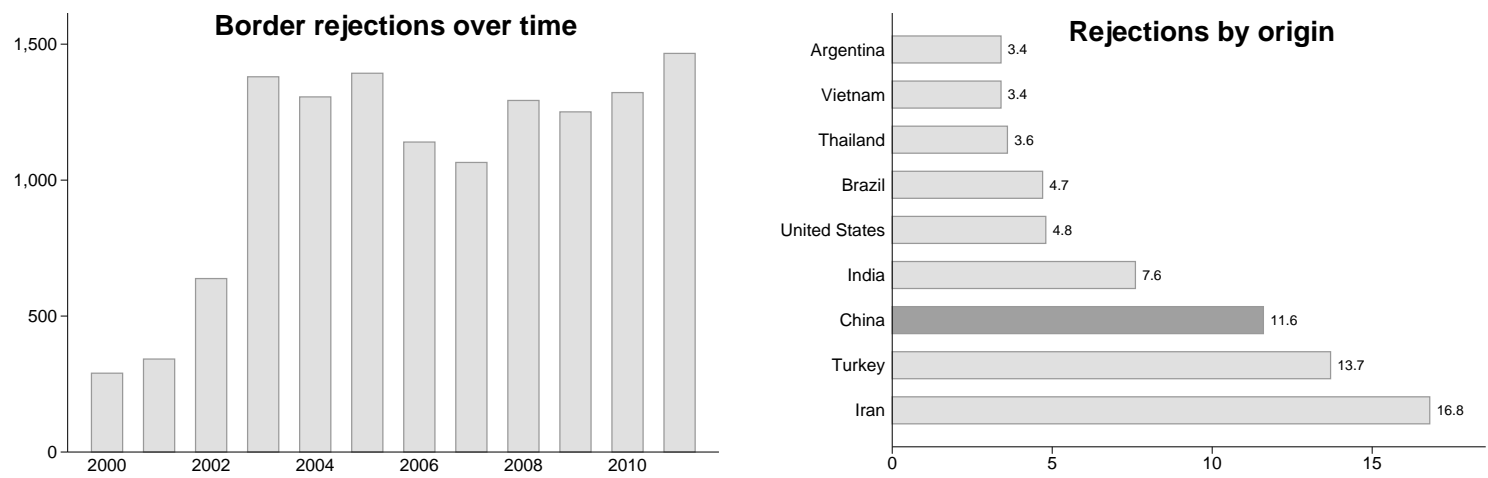

Note: Authors' computation.

Figure 3 - RASFF rejections on Chinese shipments
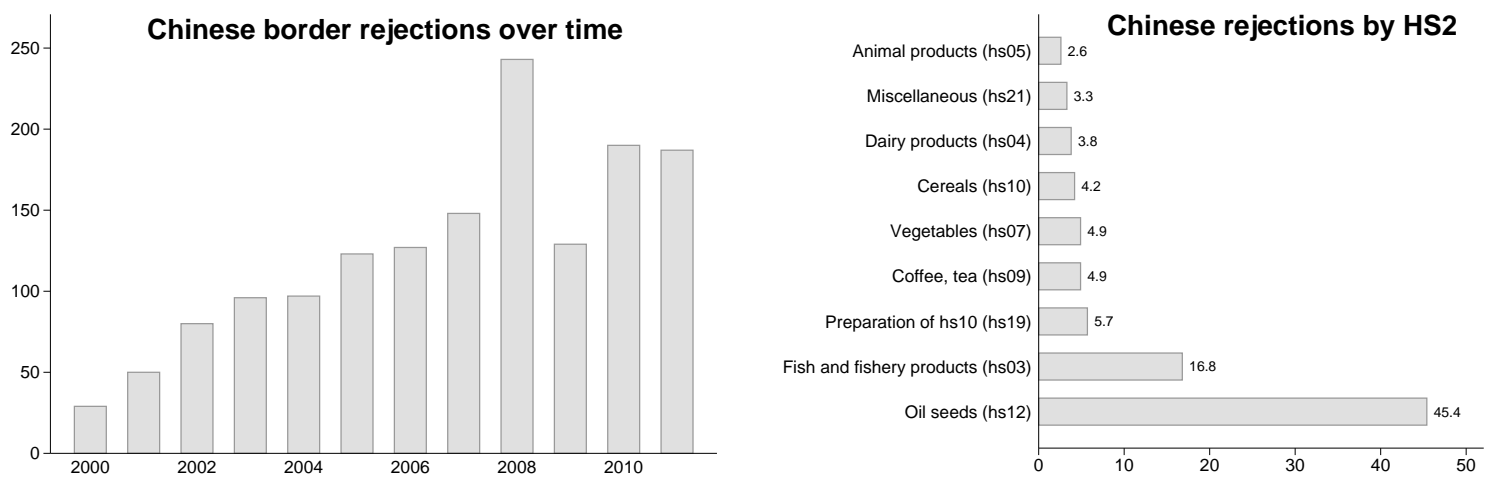

Note: Authors' computation. 


\section{Figure 4 - Correlation between current and lagged RASFF rejections}
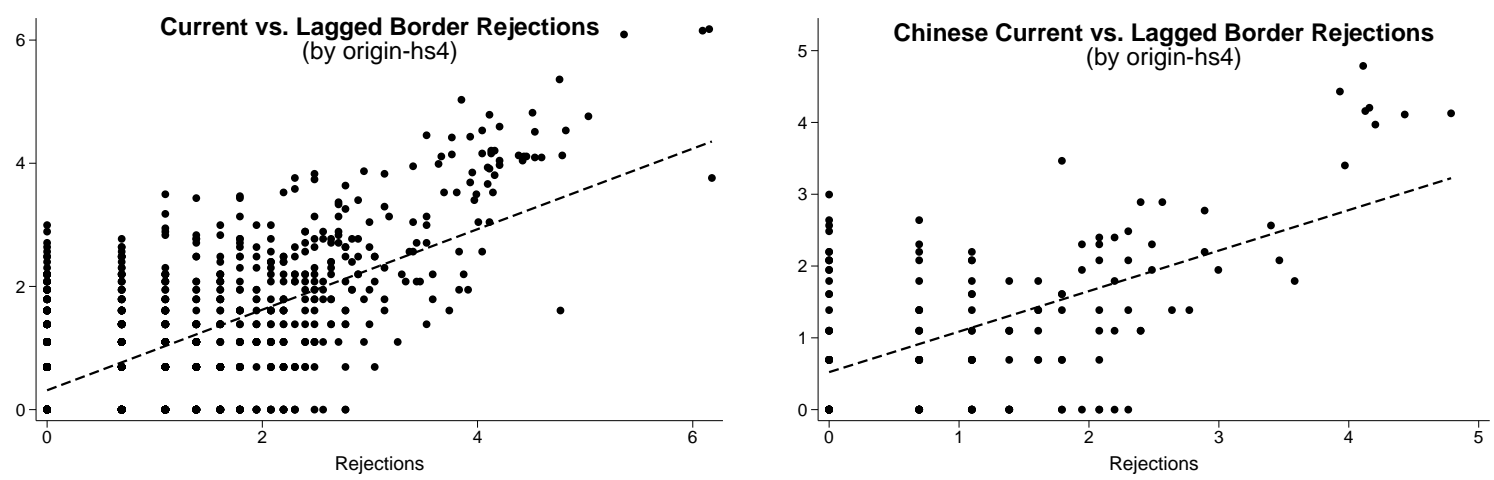

Note: Authors' computation ( $\mathrm{y}$-axis: lagged rejections (in $t-1$ ); $\mathrm{x}$-axis: current rejections (in $t$ )). 


\section{Appendix}

\section{Appendix}

\section{A. Matching RASFF rejections with HS4 product codes}

One of the contributions made by this paper is the method developed to assign product codes to the verbal descriptions provided for notifications on the RASFF portal. Attributing product codes is a prerequisite for matching sanitary rejections with Chinese export data.

To assign a product code to each notification, we exploit information on variables product category (e.g. "alcoholic beverages") and subject (e.g. "undeclared sulphite in Wine from Chile") reported by the RASFF authorities. We assign observations to the HS classification in which our Chinese firm-level data are coded. We code to the HS 4-digit level - the most disaggregated level at which we can identify notifications. We use the 2002 revision of the HS classification.

A manual assignment of HS4 codes on an individual basis is not possible given the number of notifications in our database (14,860 observations for the period 1979-2011 after the cleaning procedure described in Section 3). Therefore, to assign product codes we implement the following approach. We first split subject in order to extract the relevant information on the product (e.g. "wine"). Next, we rearrange some product categories and align them more directly with HS2 sectors (e.g. "fish and fish products" and "farmed fish and products thereof - other than crustaceans and molluscs" are combined). We also conduct some re-assignments of observations across product categories to ensure consistency. Finally, we disregard observations from product category "food contact materials" as we are only interested in agri-food products (HS chapters 01-24).

We identify the sector (HS2) wherever possible, and assign the HS4 product code using Stata's regexm function. Regexm searches for keywords associated with a specific HS4 code. For example, within product "fish", "frozen hake fillets" can be assigned HS4 code 0304 ("Fish fillets and other fish meat - whether or not minced, fresh, chilled or frozen") using keywords "fillets" and "frozen". Using the same method "chilled hake" is assigned HS4 code 0302 ("Fish, fresh or chilled, excluding fish fillets and other fish meat of heading No 0304"). The full Stata do-files with the matching correspondence and code mapping RASFF notifications and HS codes are available on request from the authors.

This methodology has several advantages. Firstly, it is easily checked, verified, and replicated, and ensures consistent treatment of RASFF observations. Secondly, it can be extended to more data at very low cost. For example, it can be applied to additional observations as more RASFF notifications become available over time.

Using this strategy, we successfully match $89 \%$ of rejections with an HS4 code $(13,241$ out of 14,860). Among border rejections applied to China we match $91 \%(1,537$ out of 1,690$)$. The 
incidence of rejections is fairly heterogeneous across products but is clustered in some sectors. Our rejections are split over 115 different HS4 codes out of potentially 201 in the 24 chapters of agri-food products (for China we identify 67 different HS4 products). If we look at all the rejections, the majority of notifications concern HSO8 "Edible fruits and nuts", HSO3 "Fish and Crustaceans, Molluscs", and HS12 "oil seeds and oleaginous fruits". For China, HS12 and HS03 are the two main chapters affected by border rejections. We conduct an additional visual check of the mapping in Table A.1. We compare the percentage of Chinese exports and rejections by HS2 product category. While we do not expect a strong correlation (small export sectors could plausibly be affected by a disproportionate number of rejections), we are able to confirm that there are no large sectors without rejections and no tiny agri-food sectors with many rejections.

Table A.1 - Chinese border rejections and percent of agri-food exports by HS2 (2000-2011)

\begin{tabular}{llcc}
\hline \multicolumn{1}{c}{ HS Chapter } & $\begin{array}{c}\text { \% Chinese } \\
\text { agri-food exports }\end{array}$ & $\begin{array}{c}\text { Nb. of } \\
\text { rejections }\end{array}$ \\
\hline 01 & Live animals & 0.1 & 0 \\
02 & Meat and edible meat offal & 0.6 & 32 \\
03 & Fish and crustaceans, molluscs & 24.5 & 258 \\
04 & Dairy produce & 0.9 & 59 \\
05 & Products of animal origin & 9.9 & 40 \\
06 & Live trees and other plants & 0.6 & 0 \\
07 & Edible vegetables & 11.2 & 75 \\
08 & Edible fruits and nuts & 4.6 & 24 \\
09 & Coffee, tea, matÃ C) and spices & 2.9 & 76 \\
10 & Cereals & 0.2 & 65 \\
11 & Products of the milling industry & 0.2 & 0 \\
12 & Oil seeds and oleaginous fruits & 7.4 & 698 \\
13 & Lac; gums, resins & 1.6 & 2 \\
14 & Vegetable plaiting materials & 0.4 & 0 \\
15 & Animal or vegetable fats and oils; & 1.2 & 1 \\
16 & Preparations of meat, of fish or of crustaceans, molluscs & 5.5 & 1 \\
17 & Sugar and sugar confectionery & 1 & 26 \\
18 & Cocoa and cocoa preparations & 0.6 & 1 \\
19 & Preparations of cereals, flour, starch or milk & 2 & 87 \\
20 & Preparations of vegetables, fruit, nuts & 17.7 & 29 \\
21 & Miscellaneous edible preparations & 1.4 & 51 \\
22 & Beverages, spirits and vinegar & 0.7 & 4 \\
23 & Residues and waste from the food industries & 2.2 & 0 \\
24 & Tobacco & 2.7 & \\
\hline
\end{tabular}

Note: Authors' computation.

\section{B. Chinese firm-level exports}

Table B.2 investigates whether aggregation of the observations at the 4-digit level is a potential source of bias. If rejections occur at the HS6 product level but our analysis is performed at the HS4 sector level, we could observe automatic higher survival rates (and lower levels of exit) for larger firms. Large firms might export multiple HS6 products within an HS4 sector. Even if one 
firm's HS6 product is affected by rejections, other HS6 products may remain unaffected. Thus, at the HS4 level, we may observe large firms as less likely to exit the RASFF market.

To address this issue, we record the number of HS6 products exported by a firm within each HS4 sector. Table B.2 summarizes the results. Columns (1) to (5) report the fractions of firm-HS4 exports that have the underlying number of HS6 products. We observe that firms even multi-HS4 firms - usually export only one HS6 product within each HS4 sector. 78.23\% of firms present in only one HS4 sector export just one HS6 product within that HS4 sector (and $15.49 \%$ of these firms export two HS6 products within that HS4 sector). At the other end of the spectrum, for firms present in 10 or more HS4 sectors, only one HS6 product per HS4 sector is exported in $65.61 \%$ of the cases (and two products in $19.31 \%$ of the cases).

\section{Table B.2 - Percentage of HS6 products within HS4 sectors for Chinese firms (2000-2011)}

\begin{tabular}{cccccccc}
\hline $\begin{array}{c}\text { Nb. of HS6 } \\
\text { exported by a firm } \\
\text { within one HS4 }\end{array}$ & 1 & 2 & 3 & 4 & 5 & & \\
\hline 1 & 78.23 & 15.49 & 3.99 & 1.38 & 0.90 & 26.06 & 4.38 \\
2 & 76.36 & 15.93 & 4.66 & 1.79 & 1.25 & 14.70 & 3.94 \\
3 & 75.72 & 15.85 & 4.87 & 1.87 & 1.69 & 9.81 & 3.54 \\
4 & 74.91 & 15.84 & 5.10 & 2.07 & 2.08 & 7.19 & 3.72 \\
5 & 74.60 & 15.85 & 5.01 & 2.28 & 2.26 & 5.54 & 3.42 \\
6 & 73.82 & 16.25 & 5.09 & 2.23 & 2.61 & 4.47 & 2.90 \\
7 & 73.48 & 16.07 & 5.33 & 2.26 & 2.86 & 3.63 & 2.77 \\
8 & 73.04 & 16.21 & 5.26 & 2.47 & 3.02 & 2.99 & 2.28 \\
9 & 72.29 & 16.62 & 5.42 & 2.48 & 3.19 & 2.51 & 2.49 \\
$10+$ & 65.61 & 19.31 & 7.16 & 3.27 & 4.64 & 23.10 & 70.56 \\
\hline
\end{tabular}

Note: Authors' computation. Columns (2)-(6): by row, fractions of firm-hs4 exports that have underlying number of HS6 products. 